\title{
ERRATUM TO
}

\section{Chapter 9}

Measuring NLR Oligomerization II: Detection of ASC

Speck Formation by Confocal Microscopy

and Immunofl uorescence

\section{Michael Beilharz, Dominic De Nardo, Eicke Latz, and Bernardo S. Franklin}

Francesco Di Virgilio and Pablo Pelegrín (eds.), NLR Proteins: Methods and Protocols, Methods in Molecular Biology, vol. 1417, DOI 10.1007/978-1-4939-3566-6_9, @ Springer Science+Business Media New York 2016

DOI 10.1007/978-1-4939-3566-6_19

Due to a typesetting error, The author name Dominic De Nardo was pluralized and was wrong in the initial version published online and in print. The correct name, as appears now in both the print and online version of the book, is:

Michael Beilharz, Dominic De Nardo, Eicke Latz, and Bernardo S. Franklin 